\title{
Perancangan Sistem Pengukuran Kapasitansi Crude Oil Menggunakan Interdigital Capasitors (IDCs) Berbasis Arduino Uno
}

\author{
Risse Entikaria Rachmanita ${ }^{1 *}$, dan Haerul Ahmadi ${ }^{2}$ \\ ${ }^{1}$ Prodi Teknik Energi Terbarukan, Politeknik Negeri Jember \\ Jalan Mastrip PO BOX 164 Jember 68121, Indonesia \\ 2 JurusanTeknofisika Nuklir, Sekolah Tinggi Teknologi Nuklir, BATAN, \\ Jalan Babarsari PO BOX 6101 Yogyakarta 55281, Indonesia \\ *E-mail: risse_rachmanita@polije.ac.id
}

\begin{abstract}
Abstrak
Arduino UNO R3 merupakan salah satu jenis microcontroller board yang murah, mudah dan berpotensi digunakan sebagai basis sebuah sistem pengukuran. Penelitian kali ini mengembangkan sistem pengukuran kapasitansi crude oil menggunakan IDCs (Interdigital Capacitors). Dengan mengetahui nilai kapasitansi crude oil, maka nilai permitivitas crude oil bisa dihitung. Data nilai permitivitas crude oil sangat diperlukan dalam pembuatan sistem pemanasan crude oil menggunakan gelombang mikro. Penelitian ini menggunakan IDCs yang dicetak pada papan PCB dengan lapisan tembaga sebagai elektrodanya. Hasil pengukuran sistem selanjutnya dibandingkan dengan hasil pengukuran PM 6303 RCL meter Phillip type A frekuensi $1 \mathrm{kHz}$ yang digunakan sebagai data referensi untuk menentukan sejauh mana kesalahan pengukuran. Dari hasil yang didapatkan bahwa nilai kesalahan dari repeatability pengukuran kapasitansi berbasis Arduino UNO R3 adalah 0,47\%. Sedangkan dari hasil uji linearitas pengukuran pengukuran kapasitansi crude oil terhadap kenaikan suhu menggunakan sensor IDCs berbasis Arduino Uno didapatkan nilai $\mathrm{R}^{2}$ adalah 0,87 . Sehingga dapat diketahui bahwa alat ukur kapasitansi berbasis Arduino UNO R3 ini telah memiliki karakteristik sensor yang cukup baik.
\end{abstract}

Kata kunci: kapasitansi, crude oil, IDCS, arduino

\begin{abstract}
Arduino UNO R3 is one of the cheapest and easiest microcontroller boards that has great potential to be used as a basis for the measurement system. This study aims to develop measurement system of crude oil capacitance by using IDCs(Interdigital Capacitors). By knowing the value of crude oil capacitance, the crude oil permittivity value can be calculated. The crude oil permittivity value data is extremely needed in making crude oil heating systems using microwaves. The study used IDC sprinted on a PCB board with a copper layer as the electrode. Then, the system measurement results were compared with the results of PM 6303 RCL meter Phillip type $A$ frequency measurement of $1 \mathrm{kHz}$ which was used as reference data to determine the extent of measurement errors. From the results obtained, it is known that the error value of the Arduino UNO R3 based capacitance repeatability measurement is $0.47 \%$. While the results of the linearity test measurement of crude oil capacitance measurement of temperature increases using the Arduino Uno-based IDCs sensor, the $R^{2}$ value is 0.87 . Thus it can be seen that the Arduino UNO R3-based capacitance measuring device has quite good sensor characteristics.
\end{abstract}

Keywords: capacitance, crude oil, IDCS, Arduino

\section{PENDAHULUAN}

Dengan semakin berkembangnya teknologi elektronika, maka alat ukur elektronik sangat diperlukan. Perancangan alat ukur sangat diperlukan terutama dalam bidang industri perminyakan. Salah satu pengukuran yang dibutuhkan adalah pengukuran parameter fisis pada Crude Oil. Dalam kamus minyak dan gas bumi, minyak bumi atau crude oil adalah campuran berbagai hidrokarbon yang terdapat dalam bentuk fase cair dalam reservoir di bawah permukaan tanah dan tetap cair pada tekanan atmosfer setelah melalui fasilitas pemisah di atas permukaan (Muntini, Pramono, Minarto, Kalsum, \& Rachmanita, 2017).

Interdigital Capacitor Sensor (IDCs) merupakan sensor yang berbentuk seperti pola sisir elektroda yang periodik dan dicetak pada 
papan dengan bahan substrat seperti silikon atau glass, biasanya juga menggunakan printed circuit board (PCB). IDCs telah dikembangkan dalam berbagai aplikasi, seperti aplikasi kontrol pada proses pengasapan, penelitian komponen dielektrik keramik dan polimer film, fabrikasi pada komponen elektronik seperti filter gelombang mikro, perlengkapan akustik, aplikasi pada transducer, dalam bidang kimia dan biologi (Igreja \& Dias, 2011). Selain itu aplikasi IDCS diterapkan untuk mengukur konduktivitas dan permitivitas bahan (Zhang, 2010), hasil penelitian menunjukkan bahwa algoritma dapat secara akurat mengekstraksi permitivitas rendah dan konduktivitas bahan yang diuji dari data impedansi yang diukur. IDCs juga digunakan untuk sensor gas dan kelembapan (Urbiztondo, Pellejero, Rodriguez, Pina, \& Santamaria, 2011), mendekteksi kandungan bahan kimia yang berbahaya pada bahan makanan laut (Mohd Syaifudin, Jayasundera, \& Mukhopadhyay, 2009), mendeteksi tetes fluida mikro (Cole \& Kenis, 2009), mendeteksi kandungan gula pada larutan gula (Angkawisittpan \& Manasri, 2012), dan meneliti sifat dielektrik fluida dengan menggunakan IDCs untuk mengukur perubahan kapasitansi fluida (Vuković Rukavina, 2014a).

Pada penelitian yang dilakukan Vuković Rukavina (2014) IDCs yang digunakan dari bahan PCB dengan konfigurasi elektroda: panjang elektroda $37 \mathrm{~mm}$, lebar elektroda $0,7 \mathrm{~mm}$, jarak antar elektroda $0,5 \mathrm{~mm}$ dan jumlah elektroda 8 buah. Hasil penelitian menunjukkan bahwa IDCs mampu digunakan untuk meneliti sifat dielektrik fluida (benzena, fenol, aseton, etanol, metanol, formaldehida dan air suling) dengan mengetahui nilai kapasitansinya (Vuković Rukavina, 2014b). Sedangkan pada penelitian ini menggunakan IDCs bahan PCB dengan konfigurasi eketroda yang berbeda dengan yang dilakukan sebelumnya, yaitu penambahan jumlah elektroda. Fluida yang akan digunakan adalah crude oil.

Interdigital capacitor sensor terdiri dari dua pola elektroda, yaitu elektroda positf dan negatif pada bidang $x y$. Setiap elektroda memiliki lebar (w) dan jarak antara dua elektrode yang berdekatan adalah $g$. Jarak spasial periodik sel interdigital dinamakan unit sel yang dapat didefinisikan sebagai jarak antara garis tengah pada elektrode dengan elektrode terdekat yang sama (Entikaria Rachmanita et al., 2018).

IDCs merupakan sensor yang berbasis pada elektroda kooplanar yang periodik. Secara operasional, prinsip IDCs sama halnya dengan kapasitor pelat sejajar. Akan tetapi, tidak seperti kapasitor pelat sejajar yang memiliki dua sisi, IDCs tidak memiliki dua sisi untuk mengakses material yang akan diuji (Rachmanita \& Ahmadi, 2019).

Hubungan antara kapasitansi persatuan panjang yang terukur oleh IDCS terhadap permitivitas bahan dapat dilihat dari persamaan berikut:

$$
C_{u c}=\varepsilon_{0}\left(\varepsilon_{r}+\varepsilon_{k}\right) \frac{\kappa\left(\sqrt{1-\left(\frac{w}{a}\right)^{2}}\right)}{\kappa\left(\frac{w}{a}\right)}+2 \varepsilon_{0} \varepsilon_{k} \frac{t}{w}
$$

Dimana, $\varepsilon_{0}$ adalah permitivitas udara atau ruang hampa, $\varepsilon_{r}$ adalah permitivitas relatif substrat, $\varepsilon_{k}$ adalah permitivitas relatif film, $\kappa$ adalah complete elliptic integral of the first kind, $t$ adalah ketebalan elektroda, $w$ adalah lebar elektroda dan a adalah jarak antar elektroda.

Sedangkan untuk menghitung kapasitansi total, adalah:

$$
C_{\text {TOTAL }}=C_{u c}(N-1) L
$$

Dimana, $N$ adalah jumlah sel elektroda dan $L$ adalah panjang elektroda (Abu-Abed \& Lindquist, 2008; Entikaria Rachmanita et al., 2018; Rachmanita, 2019).

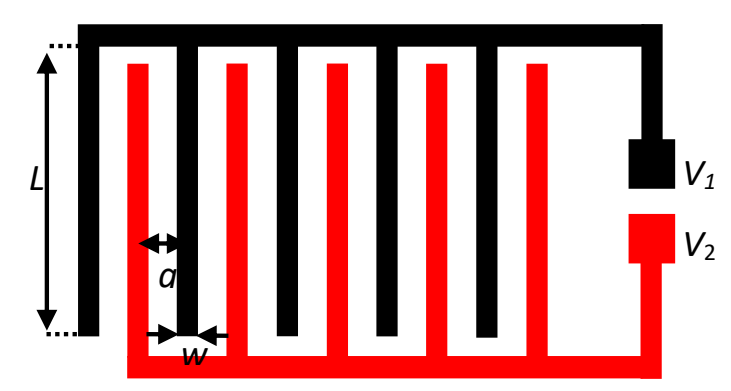

(a) 


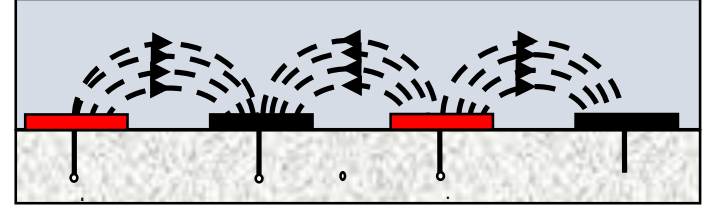

(b)

Gambar 1. (a) Pola interdigital capacitor (b) Garis-garis medan listrik pada interdigital capacitor koplanar

Pada penelitian ini IDCS diaplikasikan sebagai media sensing dalam pengukuran kapasitansi crude oil. N. Angkawisittpan et al telah melakukan penelitian mengunakan IDCs untuk medeteksi kandungan gula dalam larutan gula. Hasil penelitiannya memperlihatkan bahwa IDCs berpotensi besar untuk mendeteksi permitivitas relatif dan konsentrasi dari larutan gula (Angkawisittpan \& Manasri, 2012).

Pada Artikel ini akan dibahas tentang perancangan sistem pengukuran crude oil dengan menggunakan IDCs berbasis arduino Uno sebagai sistem pengukuran yang akan merecord data dan sekaligus menampilkan hasil pengukuran pada LCD dan monitor. Rangkaian sistem arduino uno dihubungkan dengan IDCs yang dimasukkan ke dalam bahan uji (crude oil). Monitor LCD dan monitor komputer akan menampilkan nilai kapasitansi crude oil yang terukur, sistem pengukuran ditunjukkan pada Gambar 4.

\section{METODE EKSPERIMEN}

Perancangan sistem pengukuran diawali dengan perancangan dan fabrikasi sensor. Sensor yag digunakan adalah Interdigital Capacitors (IDCs). Pada tahap ini dilakukan perancangan desain IDCs dengan spesifikasi pada Tabel 1.

Tabel 1. Desain Spesifikasi IDCS

\begin{tabular}{lc}
\hline \multicolumn{1}{c}{ Parameter } & Ukuran \\
\hline Panjang Elektroda $(\mathrm{L})$ & $30 \mathrm{~mm}$ \\
\hline Jumlah Elektroda $(\mathrm{n})$ & 10 \\
\hline Lebar Elektroda $(\mathrm{w})$ & $2,5 \mathrm{~mm}$ \\
\hline Jarak Antar Elektroda $(\mathrm{g})$ & $2,5 \mathrm{~mm}$ \\
\hline Tebal Elektroda $(\mathrm{t})$ & $0,01 \mathrm{~mm}$ \\
\hline
\end{tabular}

Desain rancangan konfigurasi IDCS dengan menggunakan desain seperti pada Gambar 1.a. Hasil cetakan pada PCB seperti pada Gambar 2.

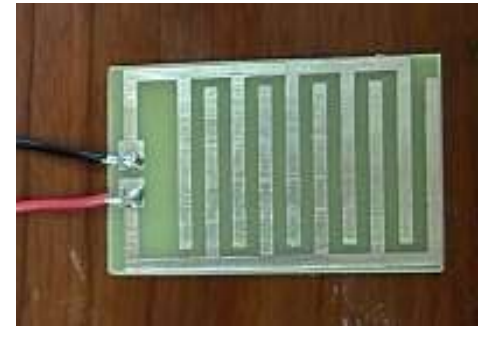

Gambar 2. Modul Interdigital Capacitor (IDCs) hasil fabrikasi

Tahapan kedua pada penelitian ini adalah perancangan sistem sensor. Sistem sensor yang dirancang berbasis arduino uno. Rangkaian sistem sensor digunakan untuk menghubungkan IDCs dengan larutan yang akan diukur nilai kapasitansinya sehingga data digitalnya dapat ditampilkan pada layar LCD dan monitor.

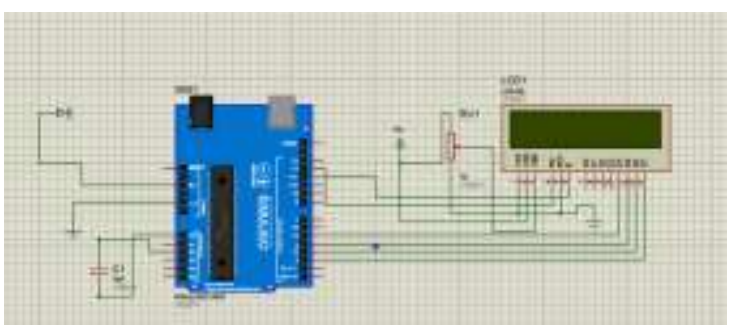

Gambar 3 Desain Rangkaian Sistem Sensor

Hal pertama yang dilakukan untuk mengukur kapasitansi IDCs dan crude oil adalah merangkai sistem pengukuran kapasitansi menggunakan alat dan bahan yang dibutuhkan. Kedua, mengukur kapasitansi IDCs. Ketiga, melakukan pengukuran kapasitansi crude oil. Sistem pengukuran kapastansi berbasis arduino uno diperlihatkan pada Gambar 4. Keempat, melakukan pengukuran kapasitansi IDCs dan kapasitansi crude oil menggunakan PM 6303 RCL meter Phillip type A frekuensi $1 \mathrm{kHz}$ seperti Gambar 5. Kemudian dilakukan analisis dari data yang diperoleh. 


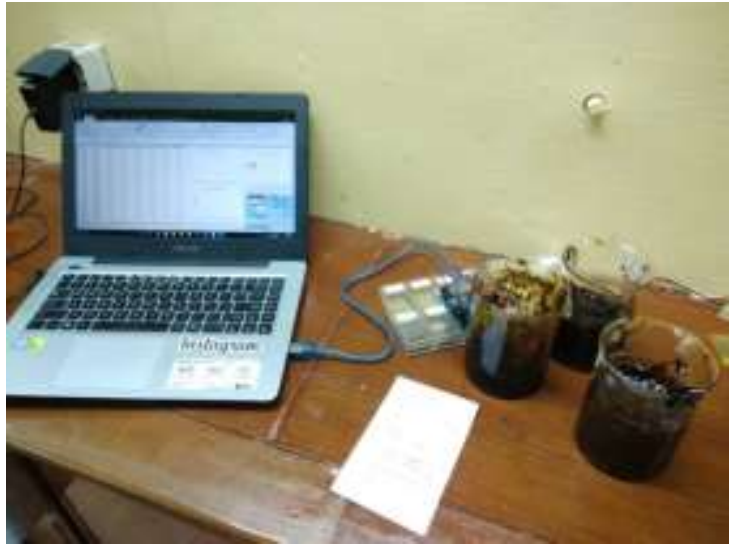

Gambar 4. Sistem Pengukuran Kapasitansi

Crude Oil Menggunakan Arduino Uno R3

Parameter observasi adalah nilai kapasitansi. Nilai kapasitansi sensor IDCs dan crude oil diukur menggunakan sensor IDCs yang dimasukkan ke dalam masing-masing fluida. Sensor ini dihubungkan dengan rangkaian sistem sensor yang telah dibuat. Nilai kapasitansi yang terukur akan ditampilkan pada layar LCD.

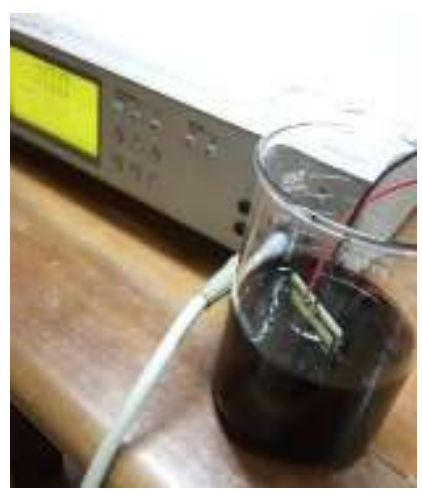

Gambar 5. Sistem Pengukuran Kapasitansi Crude Oil Menggunakan RCL Meter

\section{HASIL DAN PEMBAHASAN}

Prinsip IDCs memiliki kesamaan dengan sistem kapasitor plat sejajar. Salah satu elektrodanya dihubungkan pada sumber tegangan dan elektroda lainnya dihubungkan dengan ground, antara kedua kutub terbentuk medan magnet. Perubahan medan magnet mengindikasikan perubahan nilai impedansi dari sensor. Jika terdapat suatu stimulus pada bidang dielektrikum, maka menyebabkan perubahan nilai kapasitansi dari sensor.

HASIL
Dengan menggunakan sistem IDCs sebagai sensor maka dibuatlah modul sistem pengukuran kapasitansi pada crude oil berbasis arduino. Hasil perancangan ditunjukkan pada Gambar 6.

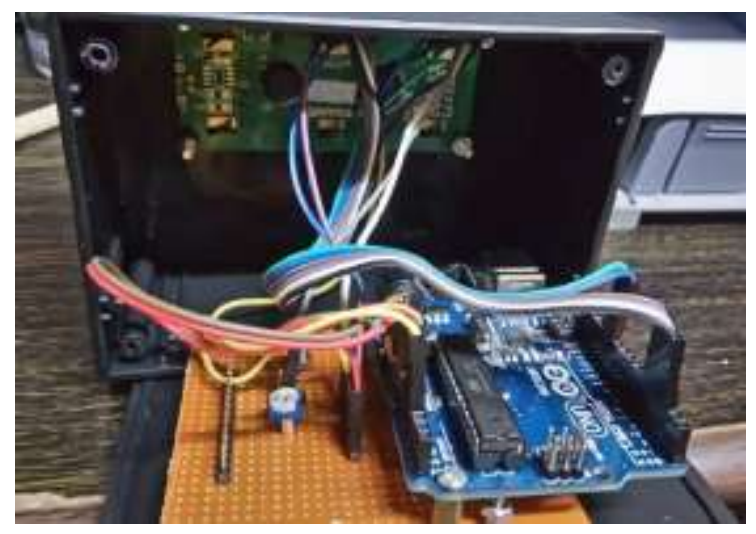

Gambar 6 Rangkaian sistem kapasitansimeter berbasis arduino

Pada penelitian ini, crude oil yang digunakan berada dalam reservoir di bawah permukaan tanah dan tetap cair pada tekanan atmosfer setelah melalui fasilitas pemisah di atas permukaan. Crude oil atau yang biasa disebut minyak mentah merupakan cairan kental berwarna coklat, mudah terbakar, dan berada di lapisan atas dari beberapa area di kerak bumi. Penyusun utama crude oil adalah komponen hidrokarbon yang terdapat dalam bentuk fase cair.Komposisi minyak bumi terdiri atas:

a. Karbon: $83,0-87 \%$

b. Hidrogen: $10,0-14,0 \%$

c. Nitrogen : $0,1-2,0 \%$

d. Oksigen: $0,05-1,5 \%$

e. Sulfur: $0,05-6,0 \%$

f. Logam $(\mathrm{Ni}$ dan $\mathrm{V}):<1000 \mathrm{ppm}$ (Shanmugam, 2012)

Secara umum minyak bumi terdiri dari campuran kompleks dari berbagai hidrokarbon, sebagian besar seri alkana, tetapi bervariasi dalam penampilan, komposisi, dan kemurniannya dan beberapa komponen nonhidrokarbon. Senyawa hidrokarbon merupakan senyawa organik yang hanya memiliki unsur karbon dan hidrogen pada setiap molekulnya. Dalam minyak bumi senyawa hidrokarbon terdiri atas hidrokarbon parafin, naftan, aromat, monoolefin dan diolefin. Senyawa-senyawa ini memiliki susunan rantai karbon dan titik didih 
yang berbeda-beda. Sedangkan senyawa nonhidrokarbon dalam minyak bumi merupakan senyawa organik terdiri atas atom unsur belerang, oksigen, nitrogen dan logam-logam khusus misalnya nikel, besi, tembaga dan vanadium yang jumlahnya relatif sedikit. Umumnya senyawa non-hidrokarbon dianggap sebagai pengotor karena dapat menyebabkan terjadinya korosi, peracunan katalis, dan penurunan kualitas minyak bumi selama proses pengolahan minyak bumi (Muntini et al., 2017).

Hasil pengukuran kapasitansi IDCs dan IDCs + crude oil dengan menggunakan modul Arduino memberikan hasil nilai yang hampir konstan yang ditunjukkan pada Tabel 2. Ratarata nilai kapasitansi IDCs adalah 7,38 pF dengan nilai rata-rata kesalahan pengukuran adalah $0,65 \%$. Rata-rata nilai kapasitansi IDCS+crude oil adalah 10,67 pF dengan nilai rata-rata kesalahan pengukuran adalah $0,47 \%$. Nilai kapasitansi crude oil dalam sistem pengukuran berbasis arduino ditampilkan dalam waktu $30 \mathrm{~ns}$.

Tabel 2 Hasil pengukuran kapasitansi IDCS dan crude oil berbasis Arduino

\begin{tabular}{|c|c|c|c|c|}
\hline No & $\begin{array}{l}\text { Nilai } \\
\text { Kapasitansi } \\
\text { IDCS } \\
\text { (a) }\end{array}$ & $\begin{array}{c}\text { Nilai } \\
\text { Kapasitansi } \\
\text { IDCS + crude } \\
\text { oil } \\
\text { (b) } \\
\end{array}$ & $\begin{array}{l}\text { Kesalahan } \\
\text { Pengukuran (\%) } \\
\text { (a) }\end{array}$ & $\begin{array}{l}\text { Kesalahan } \\
\text { Pengukuran (\%) } \\
\text { (b) }\end{array}$ \\
\hline 1 & $7,77 \mathrm{pF}$ & $10,63 \mathrm{pF}$ & 0,64 & 0,47 \\
\hline 2 & $7,60 \mathrm{pF}$ & $10,73 \mathrm{pF}$ & 0,66 & 0,47 \\
\hline 3 & $7,85 \mathrm{pF}$ & $10,88 \mathrm{pF}$ & 0,64 & 0,46 \\
\hline 4 & $7,48 \mathrm{pF}$ & $10,49 \mathrm{pF}$ & 0,67 & 0,48 \\
\hline 5 & $7,64 \mathrm{pF}$ & $10,83 \mathrm{pF}$ & 0,65 & 0,46 \\
\hline 6 & $7,81 \mathrm{pF}$ & $10,63 \mathrm{pF}$ & 0,64 & 0,47 \\
\hline 7 & $7,89 \mathrm{pF}$ & $10,34 \mathrm{pF}$ & 0,63 & 0,48 \\
\hline 8 & $7,68 \mathrm{pF}$ & $10,63 \mathrm{pF}$ & 0,65 & 0,47 \\
\hline 9 & $7,90 \mathrm{pF}$ & $10,68 \mathrm{pF}$ & 0,63 & 0,47 \\
\hline 10 & $7,75 \mathrm{pF}$ & $10,83 \mathrm{pF}$ & 0,65 & 0,46 \\
\hline
\end{tabular}

Sedangkan hasil pengukuran kapasitansi IDCs dan IDCs + crude oil yang diukur dengan menggunakan PM 6303 RCL meter Phillip type A ditunjukkan pada Tabel 3.

Jika dibandingkan dengan hasil pengukuran kapasitansi IDCs dan IDCs+crude oil dengan menggunakan PM 6303 RCL meter Phillip type A menunjukkan hasil yang hampir sama. Rata-rata nilai kapasitansi IDCs adalah 7,66 pF dengan nilai rata-rata kesalahan pengukuran adalah $0,65 \%$. Rata-rata nilai kapasitansi IDCs+crude oil adalah 10,29 pF dengan nilai rata-rata kesalahan pengukuran adalah $0,49 \%$.
Tabel 3. Hasil pengukuran kapasitansi IDCS dan crude oil menggunakan PM $6303 \mathrm{RCL}$

\begin{tabular}{ccccc}
\multicolumn{5}{c}{ meter Phillip type A } \\
\hline No & $\begin{array}{c}\text { Nilai } \\
\text { Kapasitansi } \\
\text { IDCS } \\
\text { (a) }\end{array}$ & $\begin{array}{c}\text { Nilai } \\
\text { Kapasitansi } \\
\text { IDCS + } \\
\text { crude oil (b) }\end{array}$ & $\begin{array}{c}\text { Kesalahan } \\
\text { Pengukuran } \\
\text { (\%) (a) }\end{array}$ & $\begin{array}{c}\text { Kesalahan } \\
\text { Pengukuran } \\
(\%)(b)\end{array}$ \\
\hline 1 & $7,8 \mathrm{pF}$ & $10,1 \mathrm{pF}$ & 0,64 & 0,50 \\
\hline 2 & $7,5 \mathrm{pF}$ & $10,3 \mathrm{pF}$ & 0,67 & 0,49 \\
\hline 3 & $7,5 \mathrm{pF}$ & $10,5 \mathrm{pF}$ & 0,67 & 0,48 \\
\hline 4 & $7,6 \mathrm{pF}$ & $9,9 \mathrm{pF}$ & 0,66 & 0,51 \\
\hline 5 & $7,5 \mathrm{pF}$ & $10,3 \mathrm{pF}$ & 0,67 & 0,49 \\
\hline 6 & $7,8 \mathrm{pF}$ & $10,1 \mathrm{pF}$ & 0,64 & 0,50 \\
\hline 7 & $7,9 \mathrm{pF}$ & $10,2 \mathrm{pF}$ & 0,63 & 0,49 \\
\hline 8 & $7,9 \mathrm{pF}$ & $10,4 \mathrm{pF}$ & 0,63 & 0,48 \\
\hline 9 & $7,5 \mathrm{pF}$ & $10,5 \mathrm{pF}$ & 0,67 & 0,48 \\
\hline 10 & $7,6 \mathrm{pF}$ & $10,6 \mathrm{pF}$ & 0,66 & 0,47 \\
\hline
\end{tabular}

\section{PEMBAHASAN}

Rangkaian kapasitansimeter yang telah dibuat menggunakan Arduino Uno sebagai sistem mikrokontroler. Arduino uno menggunakan sistem mikrokontroler ATmega 328 ini dijalankan dengan software arduino yang meliputi IDE (Integrated Development Environment) untuk menulis program. IDE yang digunakan disebut sketch yang dijalankan dengan bahasa pemrograman. Bahasa pemrograman yang digunakan untuk menjalankan kapasitansimeter ini adalah:

\#include <LiquidCrystal.h> const int OUT_PIN = A2; const int IN_PIN = A0;

const float IN_STRAY_CAP_TO_GND $=24.48 ; / /$ initially this was 30.00 $=0.00$; const float IN_EXTRA_CAP_TO_GND const float IN_CAP_TO_GND= IN_STRAY_CAP_TO_GND + + IN_EXTRA_CAP_TO_GND; const int $\mathrm{MAX}$ _ADC_VALUE $=1023$; LiquidCrystal $\operatorname{Icd}(12,11,5,4,3,2)$;

void setup()

\{ pinMode(OUT_PIN, OUTPUT); //digitalWrite(OUT_PIN, LOW); //This is the default state for outputs pinMode(IN PIN, OUTPUT); //digitalWrite(IN_PIN, LOW); Icd.begin(16, 2); Serial.begin(9600); \}

void loop()

\{ //Capacitor under test between OUT_PIN and IN_PIN //Rising high edge on OUT_PIN pinMode(IN_PIN, INPUT); 
digitalWrite(OUT_PIN, HIGH); int val = analogRead(IN_PIN);

measurement

//Clear everything for next

digitalWrite(OUT_PIN, LOW);

pinMode(IN_PIN, OUTPUT);

//Calculate and print result

float capacitance $=$ (float)val * IN_CAP_TO_GND / (float)(MAX_ADC_VALUE - val);

"));

Serial.print $(\mathrm{F}($ "Capacitance Value $=$

Serial.print(capacitance, 3);

Serial.print( $F(" p F("))$;

Serial.print(val);

Serial.println(F(") "));

Icd.setCursor(0, 0);

Icd.print("Capacitance=");

Icd.setCursor $(0,1)$;

Icd.print(capacitance);

Icd.print("pF");

Serial.println(capacitance);

while (millis() \% 1000 != 0)

\}

Rangkaian kapasitansi pada pengukuran sebagai berikut:

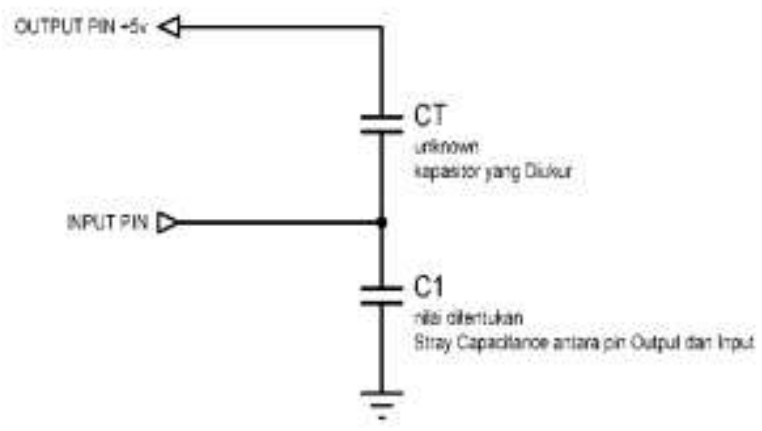

Gambar 7. Analogi rangkaian pengukuran kapasitansi

CT adalah kapasitor yang diukur. Kita mulai dengan kedua kapasitor tidak diisi dengan Pin Output pada 0 volt. Ketika Pin Output mencapai 5 volt arus listrik mengalir melalui kedua kapasitor. Tegangan pada Pin Input akan mengendap dalam $1 \%$ dari nilai akhir dalam waktu 30 ns. Nilai pada A0 akan mengendap sebanding dengan rasio CT dibagi dengan kapasitansi total, C1 + CT. Formula yang kita akan kebutuhan adalah:

menjadi

$$
V_{A 0}=\frac{V_{A 2} \times C T}{C 1+C T}
$$

$$
C 1=\frac{C T \times\left(V_{A 2}-V_{A 0}\right)}{V_{A 0}}
$$

dan

$$
C T=\frac{V_{A 0} \times C 1}{V_{A 2}-V_{A 0}}
$$

Untuk mengukur tegangan pada Pin Input $\left(\mathrm{V}_{\mathrm{A} 0}\right)$ menggunakan $\mathrm{ADC}$. Tegangan Pin Outpu $\left(V_{A 2}\right)$ besarnya 5 volt, sehingga $V_{A 0}$ akan bervariasi dari 0 sampai 5 volt, tapi bisa menggunakan nilai ADC, untuk membuat perhitungan lebih mudah. Kemudian menggunakan nilai ADC maksimum (1023) untuk $V_{A 2}$. Pada pembacaan $A D C$ yang ditampilkan pada serial monitor:

$$
\begin{aligned}
& \mathrm{CT}=7,68 \mathrm{pF} \\
& \mathrm{V}_{\mathrm{A} 2}=1023 \text { (maks) } \\
& \mathrm{V}_{\mathrm{A} 0}=366
\end{aligned}
$$

Dengan menggunakan persamaan (4) didapatkan nilai $\mathrm{C} 1=13.8 \mathrm{pF}$. Yang digunakan sebagai nilai stray capacitance pada Arduino. Hasil pengukuran kapasitansi kapasitor menggunakan kapasitansimeter yang dibuat menunjukkan nilai yang mendekati nilai sebenarnya pada nilai $22 \mathrm{pF}, 50 \mathrm{pF}$, dan $471 \mathrm{pF}$. Untuk kapasitor yang nilai kapasitansinya ribuan $\mathrm{pF}$ dan lebih dari itu kapasitansimeter yang dibuat tidak bisa memberikan nilai yang sesuai bahkan infinitive.

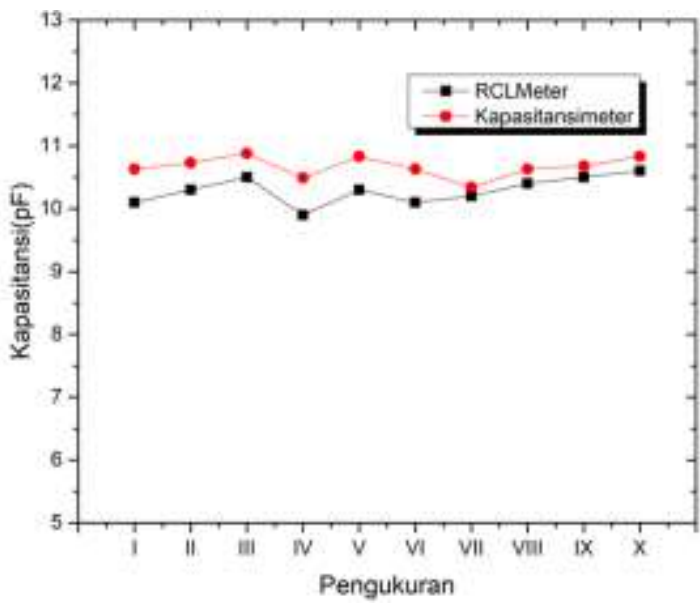

Gambar 8 Grafik Perbandingan Pengukuran pada Suhu Kamar

Pada Gambar 8 menunjukkan perbandingan hasil pengukuran dengan menggunakan RCL Meter dengan kapasitansimeter. Hasil pengukuran menunjukkan kapasitansi IDCs dan IDCs + crude oil memberikan hasil nilai yang hampir konstan. Rata-rata nilai kapasitansi IDCs adalah $7,38 \mathrm{pF}$ dengan nilai rata-rata 
kesalahan pengukuran adalah 0,65\%. Ratarata nilai kapasitansi IDCs+crude oil adalah $10,67 \mathrm{pF}$ dengan nilai rata-rata kesalahan pengukuran adalah $0,47 \%$.

Jika dibandingkan dengan hasil pengukuran kapasitansi IDCs dan IDCs+crude oil dengan menggunakan PM $6303 \mathrm{RCL}$ meter Phillip type $A$ menunjukkan hasil yang hampir sama dengan kapasitansi meter. Rata-rata nilai kapasitansi IDCs adalah 7,66 pF dengan nilai rata-rata kesalahan pengukuran adalah $0,65 \%$. Rata-rata nilai kapasitansi IDCs+crude oil adalah $10,29 \mathrm{pF}$ dengan nilai rata-rata kesalahan pengukuran adalah $0,49 \%$.

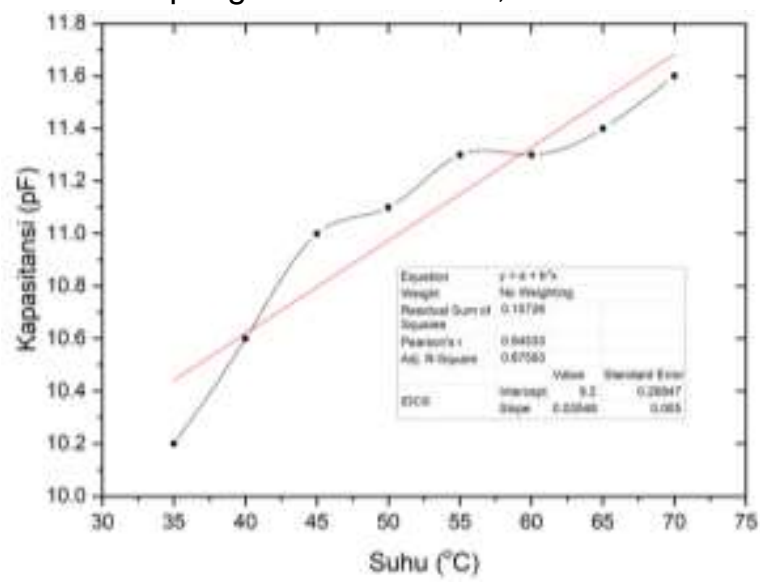

Gambar 9. Linearitas Pengukuran Kapasitansi Crude Oil Menggunakan IDCs Berbasis Arduino Uno

Linearitas sensor IDCs berbasis Arduino Uno diuji dengan melakukan pengukuran kapasitansi crude oil terhadap kenaikan suhu. Rentang pengukuran untuk uji linearitas adalah $35-70^{\circ} \mathrm{C}$ dengan variasi kenaikan $5^{\circ} \mathrm{C}$. Sebagai kalibrator, digunakan thermokople tipe $\mathrm{K}$ dengan jangkauan pengukuran sebesar $400^{\circ} \mathrm{C}$. Hasil pengukuran linearitas menggunakan IDCs diperlihatkan pada Gambar 9.

Dari grafik pada Gambar 9, terdapat kenaikan kapasitansi yang terbaca di LCD saat kenaikan temperatur crude oil. Pada temperatur $35^{\circ} \mathrm{C}$, kapasitansi crude oil teramati sebesar 10,2 pF. Ketika suhu dinaikkan setiap $5^{\circ} \mathrm{C}$, nilai kapasitansi crude oil juga semakin naik. Pada suhu $70^{\circ} \mathrm{C}$ nilai kapasitansi crude oil 11,6 pF. Berdasarkan kurva pada Gambar 9, diperoleh nilai $R^{2}$ adalah 0,87 .

\section{PENUTUP}

Spesifikasi Interdigital capacitor (IDCs) yang dibuat adalah: masing-masiing 5 elektroda positif dan negatif, panjang elektroda adalah $40 \mathrm{~mm}$, lebar elektroda adalah $4 \mathrm{~mm}$, ketebalan elektroda adalah $0,01 \mathrm{~mm}$, dan jarak antar elektroda adalah $5 \mathrm{~mm}$. Dari hasil penelitian yang telah dilakukan dapat disimpulkan bahwa: Kapasitansimeter bisa dibuat dengan menggunakan Arduino Uno R3. Range pengukuran kapasitansimeter yang telah dibuat tergantung dengan nilai stray capacitance yang ada dalam Arduino Uno R3. Kapasitansimeter yang telah dibuat bisa digunakan untuk mengukur nilai kapasitansi IDCs dan IDCs+crude oil. Nilai kapasitansi IDCs dan IDCs+crude oil hasil pengukuran menggunakan kapasitansi meter hampir sama dengan nilai hasil pengukuran menggunakan RCL meter. Nilai kesalahan hasil pengukuran repeatability kapasitansi crude oil berbasis Arduino Uno R3 adalah 0,47\%. Dari hasil uji linearitas pengukuran pengukuran kapasitansi crude oil terhadap kenaikan suhu menggunakan sensor IDCs berbasis Arduino Uno didapatkan nilai $R^{2}$ adalah 0,87 . Hal ini menunjukkan adanya kestabilan dalam pengukuran yang menunjukkan adanya kepresisian dalam pengukuran.

\section{REFERENSI}

Abu-Abed, A. S., \& Lindquist, R. G. (2008). Capacitive Interdigital Sensor with Inhomogeneous Nematic Liquid Crystal Film. Progress In Electromagnetics Research B, 7, 7587.

Angkawisittpan, N., \& Manasri, T. (2012). Determination of Sugar Content in Sugar Solutions using Interdigital Capacitor Sensor. Measurement Science Review, 12(1), 8-13.

Cole, M. C., \& Kenis, P. J. A. (2009). Multiplexed electrical sensor arrays in microfluidic networks. Sensors and Actuators B: Chemical, 136(2), 350358.

Entikaria Rachmanita, R., Suweni Muntini, M., Thawankaew, S., Chao-Moo, W., VoraUd, A., \& Seetawan, T. (2018). Fabrication and characterization of interdigital capacitors thin film by DC magnetron sputtering for measuring the permittivity of crude oil. Materials 
Today: Proceedings, 5(7, Part 1), 15192-15197.

Igreja, R., \& Dias, C. J. (2011). Extension to the analytical model of the interdigital electrodes capacitance for a multilayered structure. Sensors and Actuators A: Physical, 172(2), 392399.

Mohd Syaifudin, A. R., Jayasundera, K. P., \& Mukhopadhyay, S. C. (2009). A low cost novel sensing system for detection of dangerous marine biotoxins in seafood. Sensors and Actuators B: Chemical, 137(1), 67-75.

Muntini, M. S., Pramono, Y. H., Minarto, E., Kalsum, U., \& Rachmanita, R. E. (2017). Modeling and simulation of microwave propagation on crude oil heating. 2017 International Seminar on Sensors, Instrumentation, Measurement and Metrology (ISSIMM), 46-50.

Rachmanita, R. E. (2019). The High Capacitance for Electrode Structure of Interdigital Capacitor Thin Film Models. SNRU Journal of Science and Technology, 11(2), 55-63.

Rachmanita, R. E., \& Ahmadi, H. (2019). Aplikasi Interdigital Capacitor Sensor (IDCS) dalam pengukuran permitivitas relatif Crude Oil. Jurnal Pendidikan Fisika Dan Keilmuan (JPFK), 5(2).

Shanmugam, G. (Ed.). (2012). Handbook of Petroleum Exploration and Production, 9. In Handbook of Petroleum Exploration and Production (p. ii).

Urbiztondo, M., Pellejero, I., Rodriguez, A., Pina, M. P., \& Santamaria, J. (2011). Zeolite-coated interdigital capacitors for humidity sensing. Sensors and Actuators B: Chemical, 157(2), 450459.

Vuković Rukavina, A. (2014). Hand-held unit for liquid-type recognition, based on interdigital capacitor. Measurement, 51, 289-296. 2014.02.012

Zhang, S. (2010). Interdigitated capacitor sensor for complex dielectric constant sensing (Doctoral dissertation). http://hdl.handle.net/2152/ETD-UT2010-05-1142. 